\title{
The Emerging Threat of Ebola
}

\author{
Michelle LaBrunda and Naushad Amin
}

\section{Introduction}

Ebola is one of the deadliest infectious disease of the modern era. Over 50\% of those infected die. Prior to 1976, the disease was unknown or at least unreported. No one knows exactly where it came from, but it is postulated that a mutation in an animal virus allowed it to jump species and infect humans. In 1976 simultaneous outbreaks of Ebola occurred in what is now South Sudan and the Democratic Republic of the Congo (DRC). For 20 years, only sporadic cases were seen, but in 1995 a new outbreak occurred killing hundreds in the DRC. Since that time the frequency of these outbreaks has been increasing. It is uncertain why this is occurring, but many associate it with increasing human encroachment into forested areas bringing people and animals into more intimate contact and increased mobility of previously remote population. This chapter will navigate Ebola in the context of global health and security.

There are multiple objectives of this chapter. First is to provide a basic understanding of Ebola disease processes and outbreak patterns. Second, is to explore the interplay between social determinants of health and Ebola. The role of technology in spreading Ebola outbreaks will be explained as will Ebola's potential as a bioweapon. Readers will gain understanding of the link between environmental degradation and Ebola outbreaks.

This chapter will be divided into five main sections. These are (1) a case study; (2) Ebola Disease process; (3) Social determinants of health and Ebola; (4) Ebola in the modern era, and (5) the link between Ebola and environmental degradation.

A case study will be given to give an overview of many of the topics that will be discussed in detail in future sections. It will provide a humanitarian view of Ebola and draw from concepts from all of the other areas. The case study is of a woman

M. LaBrunda $(\varangle) \cdot$ N. Amin

University of Central Florida, Orlando, FL, USA 
who contracts Ebola. The story will be told from her perspective. She will describe from her why she thinks the outbreak has occurred. Her husband has died of Ebola despite efforts of traditional healers. She will discuss burial rites in the context of her religious beliefs.

The next section looks at the disease itself. The history, epidemiology, transmission, and signs/symptoms will be described. Prevention measures including the use of personal protective equipment and vaccination strategies will be discussed. The basics of diagnosis and treatment will be covered. The section will end with a discussion of Ebola epidemics.

Social determents of health play an important role in the epidemiology and transmission of Ebola. Factors impacting spread include, high population mobility, porous international borders, and ongoing conflict resulting in displaced populations. Poverty, cultural beliefs and practices and prior ineffective public health messages have all played a role in the emergence of Ebola.

The following section will explore Ebola in the era of technology. The role of air travel in disease spread and the effectiveness of airport screening measures will be discussed. Ebola's potential for use in bioterrorism will also be discussed in this section.

The relationship between environmental encroachment and disease emergence will be explored. Global warming, and the impact of a growing population in Ebola outbreaks will be explored.

The chapter will end with a discussion of future directions. In this last section the important of international collaborations for disease prevention and public education programs will be discussed.

\section{Case Study}

Sia waited nervously in the small one room house where she lives. She was waiting for her brother-in-law to return with the body of her dead husband, Saa. He had died yesterday of the bush illness that was killing so many in her community, Ebola the outsiders called it.

Just 2 weeks ago, the world had seemed a different place. Sia had sat with the other women of the Kissi tribe at church joking and planning for the upcoming rice harvest. Yes, they practiced Christianity, but also followed the traditions of their ancestors. Women in her village prayed to Jesus and God, but also to their ancestors. Outsiders sometimes questioned how the Kissi could follow both Christianity and their old traditions, but Sia had never seen a problem. Ancestors after all, were the ones who communicated with God. When someone in the family died, they were escorted to the realm of the ancestors where they were able to protect the living family and speak to God on their behalf. Ancestors continued to live in the village, but in their new form. Sia shivered thinking of what happened to those who died and were not escorted to the realm of the ancestors. Ceremonies were usually performed 
by the brother of the deceased. If the ceremonies were not done properly, a loved one would become a wandering ghost instead of an ancestor. Wandering ghosts torment the living bringing misfortune to everyone in the village, especially to the family that failed to perform the proper rights. Sia did not like to think of such things, but there had been several deaths in a nearby village and she could not help but to wonder if it was the work of a wandering ghost.

That was the day it started. Saa was fine when he woke up, but while they were at the church, he started to get sick. He got sick so quickly that Sia suggested that they return home early so he could rest. It wasn't a far walk, but by the time they arrived home, Saa was having chills, headache, nausea, and said his joints hurt. While Saa rested, Sia prepared a tonic to ease the pain and ward off evil spirits. Saa's eyes were red and he felt hot to touch. "A powerful spirit must be involved", Sia thought to herself. She couldn't imagine who would have cursed her husband this way. He hadn't argued with anyone that she knew.

For 3 days Sia cared for her husband with special food, potions, and prayers. She had even sacrificed a chicken, but instead of getting better he started vomiting and having diarrhea. Obviously, she needed assistance from someone with greater influence in the spirit realm. Kai, a local medicine-man of conservable powerful agreed to help but needed time to make the necessary preparations. By that evening Saa had stopped eating altogether and his gums started to bleed.

Kai belonged to a secret society that added to his powers. Sia was not allowed to attend Kai's ceremony but was told that Saa had cried blood and started to hiccough uncontrollably. Kai was notable to defeat the evil spirits even with his most powerful incantations.

Some of the villagers wanted to take Saa to a treatment center set up by some foreigners to see if they could help him. Sia was hesitant, but by the next morning Saa had developed a yellow color to his skin and was having black diarrhea, so she agreed. After a bunch of questions Saa was taken into the camp that the foreigners set up, but they would not let Sia or anyone else in the family enter. That was the last time she had seen Saa alive.

Two days later Sia was informed that Saa had died. He was to be buried in a mass grave and no one was allowed to see his body. Saa's brother said that he thinks the foreigners killed him. They weren't really there to help but part of a government plan to destroy the Kissi. Workers in the camp were removing the internal organs of the sick while they were still alive and selling them. That is why no one was allowed into the camp or to bury the bodies properly. They weren't just attacking the living, but also trying to destroy the ancestors by preventing the death ceremony from happening.

Luckily Saa's brother knew people. It had cost everything that the family owned, but the man driving the truck full of bodies agreed to meet a short distance from the foreigners' camp. He would give them the body there, but there were not to tell anyone.

As Saa's brother walked into the house carrying Saa's body, Sia felt an overwhelming sense of relief. All the worry gave her a headache and made her feel weak. Now that they had Saa's body it will be better. They will do the rituals this evening and burry Saa in the morning. He will be able to walk with the ancestors. 


\section{Ebola Virus Disease}

\subsection{Introduction and History}

One of the world's deadliest pathogen, the Ebola virus made its first appearance in 1976 in not just one but two simultaneous outbreaks. The first of its deadly attacks were in what is now known as Nzara, South Sudan while the second occurred in a small village community near the Ebola River bank in Yambuku, Democratic Republic of Congo (DRC) [122]. Of the 318 known to be infected, 280 lost their lives. Since that time, we have learned much about the Ebola virus and the disease it causes.

Ebola Virus is an uncommon virus which infects both human and non-human primates. It belongs to the family filoviridae, a negative stranded RNA virus. When magnified, it appears as a filamentous structure Fig. 1. The Ebolavirus genus has six known species, Zaire, Sudan, Tai Forest (formerly Côte d'Ivoire ebolavirus), Bundibugyo, Reston, and the recently described Bombali [48]. Reston is highly pathogenic for non-human primates and pigs, and Bombali has been discovered in free-tailed bats as part of ongoing research to discover the Ebola reservoir. The Zaire species was responsible for the first Ebola virus outbreak in 1976 and is considered to be the deadliest of the six [63]. Initially the disease caused by Ebola virus was called Ebola hemorrhagic fever, but later studies showed that the hemorrhagic manifestations were less common than initially thought and subsequently the name was changed to Ebola Virus Disease (EBD).

Until 2014, the Ebola virus isolated sporadic outbreaks occurred only in Central Africa with counts numbering in the hundreds or less, and only lasting days to weeks. However, in March 2014 the WHO confirmed an epidemic of the Zaire species of Ebola virus emerging in West Africa. This outbreak lasted 2 years and grew to be one of the world's deadliest epidemics. There were 29,000 case and 11,000 fatalities documented by the World Health Organization (WHO).

Fig. 1 Transmission electron micrograph showing some of the ultrastructural morphology displayed by an Ebola virus virion Centers for Disease Control and Prevention

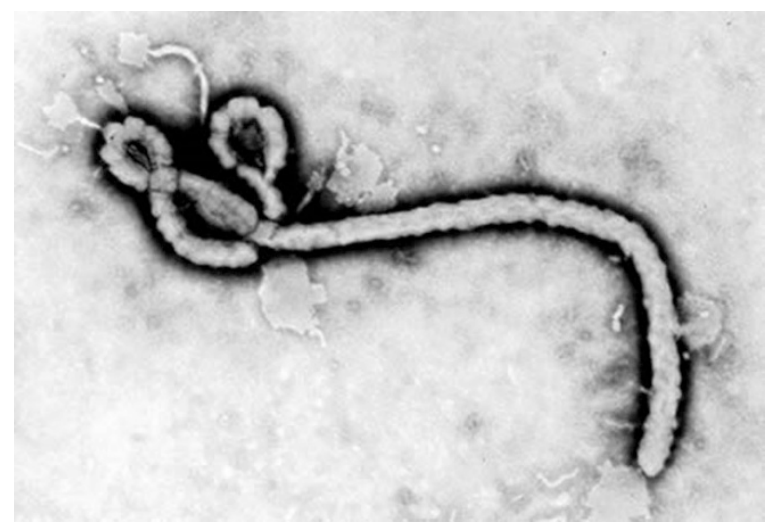


The index case of this epidemic is thought to be a 2-year-old child who became ill in late 2013. The child eventually succumbed to the illness with symptoms of fever, chills, vomiting, and black-tarry stool [117]. This was in Guinea, West Africa a country where Ebola supposedly did not exist. From here it spread to Liberia, Sierra Leone, Nigeria, and Mali.

The natural reservoir of Ebola virus is not known with certainty, although research has suggested that it may be bats. Human infection may occur through direct contact with the mystery reservoir or through contact with infected primates. This can occur when hunting and preparing bush-meat or via contact with body fluids from an infected person. Ebola is highly transmissible.

The disease pattern of EVD has shifted over the last 10 years. Currently, Ebola has been found across Central and West Africa, with occasional exported cases to other regions. For obscure reasons, outbreaks seem to be occurring with increasing frequency. This may be linked to environmental degradation and increasing mobility of local populations.

Ebola spread is through contaminated body fluids. Unfortunatly, traditional funerary practices across Africa put funeral attendees in contact with body fluids from those who have died of Ebola. Initial international efforts to control Ebola spread during outbreaks have often resulted in clashes and conflict as control measures confront tradition. Inadequate public health messages, distrust of those providing the health messages, political instability, and regional conflict have allowed Ebola to spread and kill thousands when early containment could have been within reach.

Ebola is one of the most fatal infectious diseases humans have encountered. Even with the best medical care the disease is deadly. Unfortunatly, the developing countries where EVD occurs are not equipped with optimal medical or public health facilities. To complicate the situation further, survivors of EVD are not hailed as heroes, but instead may be left with chronic illness and stigmatized in their communities.

\subsection{Transmission}

Transmission of Ebola disease is still being studied, but it is known that person-toperson contact is the most common form of spread. Infection occurs primarily through direct contact with body fluids from infected people or animals (Fig. 2). Viral antigens have been isolated from the skin of those infected suggesting that skin contact alone may be sufficient to spread disease [128]. It has also been shown that, at least in primates, Ebola can be spread through intramuscular injection, and inoculation can occur through contact of the conjunctiva or oral mucosa with infected body fluids [61]. Blood, vomitus, and feces are the body fluid most likely to spread infection because of the frequency with which they are encountered during the course of the illness, but other fluid such as urine, semen, vaginal fluid, tears, sweat, and breast milk also have potential for viral transmission $[2,5,70,88$, 97, 112]. 


\section{Ebolavirus Ecology}

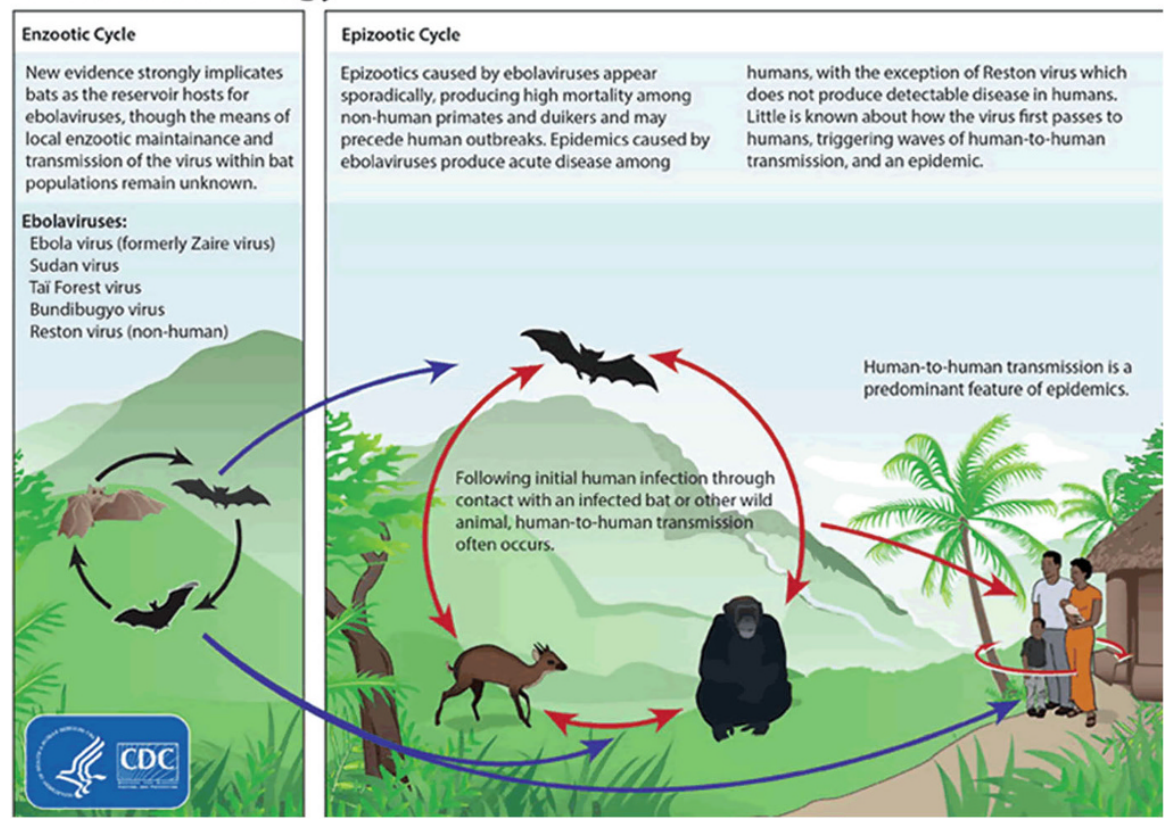

Fig. 2 Ebola ecology

Caring for an infected person with Ebola, whether at home or in the hospital has been identified as a high-risk activity for acquiring Ebola. Household members who provide direct care to an Ebola victim are 25-30 times more likely to contract Ebola than household members who share a residence but do not participate in patient care [9, 34].

Healthcare workers are also at high risk for acquiring Ebola. One study found the risk of developing EVD for healthcare workers to be 100 times that of the general community during an outbreak of Ebola in Sierra Leone [67]. There are many factors contributing to the spread of Ebola amongst healthcare workers. The presentation of Ebola is non-specific so early on in the disease process it may be diagnosed as malaria, influenza, or other non-specific viral illness. If a patient is initially misdiagnosed, then proper protective measures to limit the spread of Ebola will not be initiated. Also, the use of personal protective equipment (PPE) including gloves and gowns for routine patient care is less common in developing countries than in more developed countries due to financial restriction.

There is a risk of iatrogenic spread of Ebola. In the initial outbreak of 1976, health care workers reusing glass syringes and needles in a community clinic may have inadvertently caused spread of infection. The facility consisted of a 120-bed hospital and a busy outpatient center which treated between 6000 and 12,000 people per month. At the beginning of each day, nurses were given five syringes each which were reused after a warm water rinse. Unfortunatly, this is where Ebola made its first 
appearance. Potentially hundreds were exposed from this clinic alone $[12,122]$. There have been many other instances where hospitals have turned into epicenters for Ebola outbreaks [86, 103]. Early detection and isolation is key to preventing similar incidents in the future.

The greatest risk of transmission of EVD from human to human occurs when a patient is acutely ill. Risk also corelates with severity of illness. The sicker a patient is the more infective she is. In early phase of acute illness, the viral load is relatively low, however it increases exponentially during the latter part of the acute illness, and high viral loads are associated with high mortality rates and infectivity [43].

Those who handle corpses of Ebola victims after death also run considerable risk of acquiring the disease. Many funerary customs in Ebola-prone regions involve extensive physical contact with the dead body. Despite the risk of transmission, many still engage in these traditional practices. Without these preparations, some local traditions hold that misfortune will plague the living and the dead will not be able to pass into the spirit realm. Family who do not engage in expected funerary practice may be viewed negatively in the communities where they live. One funeral ceremony alone has been linked to 85 additional cases of Ebola [113].

Transmissibility of Ebola virus depends on the phase of infection of the ill-person. The viral load corresponds to the severity of illness [107]. In other words, the sicker a person is, the higher concentration the concentration viral particles in the blood stream. As an ill person succumbs to Ebola, they become more debilitated and require more care. At the same time, the viral load increases as the victim declines. Because of this, family caring for the ill are more likely to be infected in the later stages and corpses of those killed by Ebola are highly infectious [47].

Even after a person has recovered from Ebola and no virus can be isolated from blood, it may still be found in other tissues and able to transmit disease. Live virus has been isolated from breastmilk after recovery raising the issue of transmission to mother to infant [5]. Ebola has been isolated from semen up to 9 months after onset of symptoms, in urine for 30 days, sweat for 40 days, aqueous humor of the eye for 14 weeks, and in cerebral spinal fluid for 10 months [35, 58, 70, 97, 112]. There has been at least one case where a man who recovered from Ebola transmitted the infection to a sexual partner 200 days after his initial illness [79].

To prevent sexual transmission of Ebola, the WHO recommends systematic testing for Ebola virus in semen. For the first 3 months after infection, the semen of male Ebola survivors should be assumed to be infectious. Three months after the day symptoms started semen testing for Ebola should be initiated. If the result is negative, then it should be repeated in 1 week. If the test is positive, then it should be repeated monthly until a negative result is obtained. Once two consecutive negative results have been obtained sexual activities can be resumed [119]. Vaginal secretions have been found to contain virus up to 33 days after the initiation of symptoms, but no official testing recommendations exist for vaginal secretions [29, 56].

Other methods of Ebola spread have been postulated, but do not appear to be significant sources of transmission. Surfaces contaminated with body fluids produce a theoretical risk of transmission, but no confirmed documented cases of fomite 
transmission of Ebola exist. Ebola virus has been shown to persist in the environment supporting the need for close attention to decontamination of surfaces $[92,116]$. Medical procedures can augment disease spread if proper precautions are not taken [66].

Hunting and capturing infected animals for bush meat or for trading in black market as exotic pets can result in exposure and transmission of Ebola. There have been numerous instances of human infection resulting from contact with dead primates [8, 87]. Contact with wild primates, especially those found dead should be avoided to curb the risk of contracting Ebola.

There is another step in Ebola transmission that continues to be elusive. Humans and other primates can catch Ebola from each other, but they are not the reservoir. The reservoir is not known with certainty, but there is some evidence linking bats to Ebola [48]. The evidence for bats as the Ebola reservoir is suggestive but not compelling. Antibodies against Ebola have been found in bat species, but the significance of this is unclear. Antibodies are formed when an organism has been exposed to an infectious organism. This is evidence of exposure and immune response, but not of long-term infection or viral shedding [33]. Only one small study has ever isolated Ebola RNA from bats [72]. Attempts to infect bats then isolate viral RNA or shedding have not met with success [62, 93]. As the systematic search for the reservoir continues, negative findings are as important as positive one. Plants and arthropods have not been shown to harbor Ebola [96, 105].

\subsection{Clinical Presentation}

Ebola Virus Disease is an acute febrile illness that has been associated with hemorrhagic manifestations. It has an incubation period of 2-21 days, but presentation of symptoms is most common between day 6 and 12 after exposure [99]. It is unclear whether or not infected people can transmit disease prior to developing symptoms, but those with symptoms should be assumed to be contagious.

EVD typically begins with abrupt onset of malaise, fever, and chills. It is also common to experience vomiting, headache, diarrhea, and loss of appetite early in the disease course. The diarrhea can be profuse and water losses of up to 101 per day have been reported [76]. Dehydration and hypovolemic can result. Relative bradycardia can also be seen in Ebola [17]. A maculopapular rash commonly develops 5-7 days after onset of illness. The rash is not a consistent finding and seems to vary from region to region [99].

Hemorrhage is the most dramatic symptom associated with EVD but is not as common as first feared. Usually it manifests as gastrointestinal bleeding, but petechia, ecchymosis, bleeding oral mucosa can also be seen [121]. Bleeding is multifactorial and likely due to a combination of thrombocytopenia, coagulopathy from liver involvement, and in some instance Disseminated Intravascular Coagulation (DIC). 
EVD can cause involve a number of different organ systems. Neurologically, it can cause meningoencephalitis, confusion, chronic cognitive decline, and seizures. Neurological symptoms typically occur 8-10 days after onset of illness [27, 32]. Cardiomyopathy and respiratory muscle fatigue have been described [110]. Eye involvement is also common early in the disease course and may persist. Patients frequently report blurred vision, photophobia and blindness [102]. Laboratory findings during the course of the infection can include leukopenia, elevated renal profile, abnormal coagulation panel, thrombocytopenia, anemia, and elevated liver function tests [69]. Hiccoughs are common late in the acute phase of illness.

Symptoms typically abate after 2 weeks of illness. Even after the acute illness has resolved, Ebola victims can have long term symptoms. These include fatigue, insomnia, headaches, myalgias, arthralgias, cognitive decline, and hair loss. Uveitis and hearing loss are both common after recovery from EVD [59, 97].

Even after the resolution of acute EVD, new symptoms can develop. In a 2016 study looking at early clinical sequela, $76 \%$ of Ebola survivors developed arthralgias, $60 \%$ ocular symptoms, $24 \%$ auditory symptoms, and $18 \%$ uveitis [80]. Studies evaluating the long -erm sequela of EVD are ongoing.

\subsection{Prevention}

Prevention strategies for Ebola are numerous, but essentially boils down to avoiding all contact with skin and body fluids that could potentially harbor the Ebola virus. Of course, this is more easily said than done especially in health care settings, and for families of those infected. Health care providers deal with rapidly changing conditions often in limited resource settings and are at high risk for contracting Ebola if prevention protocols are not followed. Families of Ebola victims face similar, but even more daunting challenges. Ebola may be found in secretions of those who have recovered for months or even years after the acute illness has resolved. While not common, cases of transmission have occurred months after a person has recovered. Active Ebola virus can persist in urine, vaginal secretions, breast milk, semen, ocular fluid, and cerebrospinal fluid even after recovery making prevention more challenging.

While not heavily researched as an effective prevention strategy, people who eat bushmeat should be encouraged to take precautions to prevent Ebola infection. This means avoiding contact with fluids from slaughtered animals as much as possible. Ebola virus is inactivated by thorough cooking, so through cooking of bush meat should be encouraged [55].

\subsubsection{Health Care Settings}

Ebola is highly pathogenic and easily transmitted. Both the WHO and the Center for Disease Control (CDC) have published detailed guidelines on prevention which are 
freely available online $[54,118,124]$. The WHO recommends the following key elements to prevent transmission of Ebola virus in the hospital setting:

- Hand hygiene

- Gloves

- Facial protection (covering eyes, nose and mouth)

- Gowns (or overalls)

- Sharps safety

- Respiratory hygiene for both health care providers and patients

- Environmental cleaning

- Safe linen transport and cleaning

- Proper waste disposal

- Proper sanitation of patient care equipment

Ebola prevention requires attention to and special training in donning and removing personal protective equipment (PPE). Specific instructions and videos for use of this equipment is available at the WHO prevention CDC websites.

Health care workers who use PPE equipment properly are safe from Ebola infection, but can develop other health issues from the PPE itself. The PPE suits are hot, uncomfortable, and require constant surveillance to ensure that all the equipment remains in place and undamaged. Areas prone to Ebola outbreaks tend to be hot, humid, and lack resources for air conditioning, wearing Ebola suits creates a risk for development of heat related illness and dehydration. The CDC has published guidelines for preventing heat related illness for those providing care to Ebola patients in hot African climates [18].

\subsubsection{Prevention after Recovery}

As previously mentioned, people have survived initial Ebola infection may still be able to transmit the disease to others. With proper preventive measures the risk of transmission can be ameliorated. As with other aspects of Ebola, both the CDC and WHO have published extensive guidelines available on their websites. For healthcare workers, no special precautions are needed for basic patient care. The CDC does recommend that additional PPE be used when caring for Ebola survivors if contact with testes, urine, breast, breast milk, spinal fluid, or intraocular fluid is anticipated during patient care [57].

In the home, additional precautions may be needed. Cases of transmission through sexual contact and breast milk have been describe in the literature $[28,104]$.

CDC guidelines recommend abstinence from sexual activity of all types including oral, anal, and vaginal. If abstinence is not possible then condoms and avoidance of contact with semen is recommended. The WHO has recommended that semen be tested 3 months after the onset of disease in men. If the test is negative, then it should be repeated in 1 week. After two negative test sexual activity can be resumed. If the test is positive, it should be repeated every month until a negative test is obtained. 
Once a negative test occurs, it should be repeated in 1 week, and after two negatives sexual activity can be resumed [56].

Maternity issues around Ebola are complex. It is unclear when it is safe for a woman to become pregnant after recovering from Ebola. Some organizations have suggested that a woman wait a few months prior to becoming pregnant, but so far this recommendation has not been supported by clinical data. Breastmilk can transmit Ebola virus from a mother who has recovered from EVD to her child. If feasible, breastfeeding should be avoided. The data on Ebola transmission through breasting is limited, and resources in Ebola-prone areas make repeat testing of breastmilk impractical. Suggested strategies have recommended avoiding breasting feeding for 2 months after recovery [10].

\subsubsection{Travel}

Travel restrictions may occur during Ebola outbreaks. It is generally accepted practice that those who have potentially been exposed to Ebola virus not travel for 21 days after the last possible day of their exposure. As an alternative for those at low risk, close monitoring with no restrictions on travel may be done. Balancing individual rights with community safety creates ethical and regulatory challenges in cases of potential exposure. Additional information on monitoring and travel restriction can be found at both the CDC and WHO websites.

\subsubsection{Vaccination}

Vaccination development is in place, but there is currently no Federal Drug Administration (FDA) approved vaccination for Ebola. Currently, there are 14 different clinical trials running with the goal of developing a safe and effective Ebola vaccine [74]. An investigational vaccine called rVSV-ZEBOV is presently being used in DRC under "compassionate use". This vaccine is specific for the Zaire strain of Ebolavirus. This same vaccine was previously administered to 16,000 volunteers during an outbreak in 2015. So far, the vaccine appears safe with few side effects, but insufficient data is available for licensing [120]. Preliminary reports suggest an efficacy of $100 \%$, but duration of protection is currently not known [82].

\subsection{Diagnosis}

Even though there are no specific therapies to treat Ebola, diagnosis is important to prevent spread and to ensure administration of appropriate supportive care and monitoring. Anyone who has had any potential exposure to Ebola in the last 21 days should be evaluated if symptoms of Ebola develop. While awaiting the result of Ebola testing, appropriate infection control practices should be 
implemented. Diagnosis is done by reverse-transcription polymerase chain reaction (RT-PCR). The test should be done 3 days after the onset of symptoms [7]. False negatives can occur if the lab is collected before $72 \mathrm{~h}$ of symptom onset. A positive test confirms Ebola virus disease and that the patient is infective. Considering repeat testing in patients whose clinical picture is highly suspicious of EBD and have a negative initial test.

Ebola Virus Disease has a broad differential, and simultaneous testing for other illnesses should be undertaken as clinically warranted. This differential includes, malaria, Lassa fever, typhoid fever, influenza, meningococcal meningitis (Neisseria meningitidis), measles, Crimean-Congo Hemorrhagic Fever, Yellow Fever, Marburg, and the familiar travelers' diarrhea among many others [7].

\subsection{Treatment}

Supportive care is the only treatment for Ebola. There are no antimicrobial agents proven to be effective in EBD. When possible, care should be provided at a facility familiar with the clinical progression of Ebola. Supportive care in Ebola is no different than for any other critically ill patient.

Give intravenous fluids to prevent dehydration and shock. Patients with Ebola suffer from vomiting and diarrhea and may easily dehydrate. If intravenous fluids are unavailable or prohibitively expensive, oral hydration should be undertaken. Ebola can lead not only to hypovolemic shock, but also septic shock [11] so close patient monitoring is warranted. Electrolytes will require close monitoring and should be repleted as needed. Vasopressors may be required if blood pressure cannot be maintained.

Ebola can result in significant hematological abnormalities [52, 83]. It can also lead to liver failure followed by coagulopathy [60]. Thrombocytopenia, leukopenia, and anemia are all common and treatment should be based on the specific abnormality encountered.

Other management may include antipyretics, respiratory support, analgesics, antimotility agents for diarrhea, antiemetics for nausea and vomiting, antibiotics, nutritional support and renal replacement therapy. These and other supportive measures must be tailored to the individual patient need.

\section{Epidemiology and Outbreaks}

The first reported outbreak of Ebola-like illness occurred in 1976 in Sudan and Zaire [45] [now South Sudan and the Democratic Republic of Congo (DRC)]. It is probable that sporadic outbreaks happened earlier but were not identified. Outbreaks appear to be occurring more frequently than before. This is not only due to improved detection techniques, but also due to environmental encroachment, increasing 
population mobility, and changing weather patterns. The following section will summarize data on known Ebola outbreaks that have occurred since 1976.

\begin{tabular}{|c|c|c|c|}
\hline Date & Location & $\begin{array}{l}\text { Cases and } \\
\text { Deaths }\end{array}$ & Notes \\
\hline \multirow[t]{2}{*}{1976} & \multirow[t]{2}{*}{ DRC } & Cases: 318 & Zaire species \\
\hline & & Deaths: 280 & $\begin{array}{l}\text { Index case was a 44-year-old } \\
\text { male teacher who had just } \\
\text { returned from a } 10 \text {-day road } \\
\text { trip. He had eaten monkey and } \\
\text { antelope during his travel. He } \\
\text { presented with malaria symp- } \\
\text { toms [122] }\end{array}$ \\
\hline \multirow[t]{2}{*}{1976} & \multirow[t]{2}{*}{ South Sudan } & Cases: 284 & Sudan species \\
\hline & & Deaths: 151 & $\begin{array}{l}\text { Index cases: Three people } \\
\text { whose only common activity } \\
\text { was employment in the same } \\
\text { cotton factory presented with } \\
\text { hemorrhagic fever. The only } \\
\text { known common plant or animal } \\
\text { exposure was cotton, rats, and } \\
\text { mosquitos [123] }\end{array}$ \\
\hline \multirow[t]{2}{*}{1979} & \multirow[t]{2}{*}{ South Sudan } & Cases: 34 & Sudan species \\
\hline & & Deaths22 & $\begin{array}{l}\text { Index case was a male admitted } \\
\text { to the hospital with nausea, } \\
\text { vomiting, and fever. Unknown } \\
\text { animal exposure [4]. }\end{array}$ \\
\hline \multirow[t]{2}{*}{1994} & \multirow[t]{2}{*}{ Gabon } & Cases: 52 & \multirow[t]{2}{*}{ Zaire species } \\
\hline & & Deaths: 32 & \\
\hline \multirow[t]{2}{*}{1995} & \multirow[t]{2}{*}{ DRC } & Cases: 315 & \multirow[t]{2}{*}{ Zaire species } \\
\hline & & \begin{tabular}{|l} 
Deaths: \\
250
\end{tabular} & \\
\hline \multirow[t]{2}{*}{1996} & \multirow[t]{2}{*}{ Gabon } & Cases: 37 & \multirow[t]{2}{*}{ Zaire species } \\
\hline & & Deaths: 21 & \\
\hline \multirow[t]{2}{*}{1996} & \multirow[t]{2}{*}{ Gabon } & Cases: 60 & \multirow[t]{2}{*}{ Zaire species } \\
\hline & & Deaths: 45 & \\
\hline \multirow[t]{2}{*}{2000} & \multirow[t]{2}{*}{ Uganda } & Cases: 425 & \multirow[t]{2}{*}{ Sudan species } \\
\hline & & \begin{tabular}{|l} 
Deaths: \\
224
\end{tabular} & \\
\hline \multirow[t]{2}{*}{2001} & \multirow[t]{2}{*}{ Gabon } & Cases: 95 & \multirow[t]{2}{*}{ Zaire species } \\
\hline & & Deaths: 53 & \\
\hline \multirow[t]{2}{*}{2001} & \multirow[t]{2}{*}{ DRC } & Cases: 57 & \multirow[t]{2}{*}{ Zaire species } \\
\hline & & Deaths: 43 & \\
\hline \multirow[t]{2}{*}{2002} & \multirow[t]{2}{*}{ DRC } & Cases: 143 & \multirow[t]{2}{*}{ Zaire species } \\
\hline & & \begin{tabular}{|l|} 
Deaths: \\
128 \\
\end{tabular} & \\
\hline \multirow[t]{2}{*}{2003} & \multirow[t]{2}{*}{ DRC } & Cases: 35 & \multirow[t]{2}{*}{ Zaire species } \\
\hline & & Deaths: 29 & \\
\hline
\end{tabular}




\begin{tabular}{|c|c|c|c|}
\hline Date & Location & $\begin{array}{l}\text { Cases and } \\
\text { Deaths } \\
\end{array}$ & Notes \\
\hline \multirow[t]{2}{*}{2004} & \multirow[t]{2}{*}{ South Sudan } & Cases: 17 & \multirow[t]{2}{*}{ Sudan species } \\
\hline & & Deaths: 7 & \\
\hline \multirow[t]{2}{*}{2007} & \multirow[t]{2}{*}{ DRC } & Cases: 264 & \multirow[t]{2}{*}{ Zaire species } \\
\hline & & $\begin{array}{l}\text { Deaths: } \\
187 \\
\end{array}$ & \\
\hline \multirow[t]{2}{*}{2007} & \multirow[t]{2}{*}{ Uganda } & Cases: 149 & \multirow[t]{2}{*}{ Bundibugyo species } \\
\hline & & Deaths: 37 & \\
\hline \multirow[t]{2}{*}{2008} & \multirow[t]{2}{*}{ DRC } & Cases: 32 & \multirow[t]{2}{*}{ Zaire species } \\
\hline & & Deaths: 15 & \\
\hline \multirow[t]{2}{*}{2012} & \multirow[t]{2}{*}{ Uganda } & Cases: 11 & \multirow[t]{2}{*}{ Sudan species } \\
\hline & & Deaths: 4 & \\
\hline \multirow[t]{2}{*}{2012} & \multirow[t]{2}{*}{ DRC } & Cases: 36 & \multirow[t]{2}{*}{ Bundibugyo species } \\
\hline & & Deaths: 13 & \\
\hline \multirow[t]{2}{*}{2012} & \multirow[t]{2}{*}{ Uganda } & Cases: 6 & \multirow[t]{2}{*}{ Sudan species } \\
\hline & & Deaths: 3 & \\
\hline \multirow[t]{3}{*}{ 2014-2016 } & (1) Started in Guinea & $\begin{array}{l}\text { Cases: } \\
28,616\end{array}$ & $\begin{array}{l}\text { According to the CDC contact } \\
\text { tracing linked first case to an } \\
18 \text {-month old boy }\end{array}$ \\
\hline & $\begin{array}{l}\text { (2) Spread to Sierra Leone and } \\
\text { Liberia }\end{array}$ & \multirow[t]{2}{*}{$\begin{array}{l}\text { Deaths: } \\
11,310 \text { [38] }\end{array}$} & \multirow[t]{2}{*}{ Zaire species [39] } \\
\hline & $\begin{array}{l}\text { (3) Spread to Italy, Mali, Nige- } \\
\text { ria, Senegal, Spain, the United } \\
\text { Kingdom, and the United States } \\
\text { [39] }\end{array}$ & & \\
\hline \multirow[t]{2}{*}{2014} & \multirow[t]{2}{*}{$\mathrm{DRC}$} & Cases: 66 & Zaire species. \\
\hline & & Deaths: 49 & $\begin{array}{l}\text { The index patient - pregnant } \\
\text { woman who butchered a mon- } \\
\text { key that had been found dead by } \\
\text { her husband [77] }\end{array}$ \\
\hline \multirow[t]{2}{*}{2017} & \multirow[t]{2}{*}{ DRC } & Cases: 8 & \multirow[t]{2}{*}{ Zaire species } \\
\hline & & Deaths: 4 & \\
\hline \multirow[t]{2}{*}{2018} & \multirow[t]{2}{*}{ DRC } & Cases: 54 & \multirow{2}{*}{ Zaire species } \\
\hline & & Deaths: 33 & \\
\hline \multirow[t]{4}{*}{2018} & DRC & In-progress & Zaire species \\
\hline & & $\begin{array}{l}\text { As of } \\
11 / 29 / \\
2018:\end{array}$ & \\
\hline & & Cases & \\
\hline & & \begin{tabular}{l}
\multicolumn{1}{c}{ Con- } \\
firmed \\
cases: 380
\end{tabular} & \\
\hline
\end{tabular}




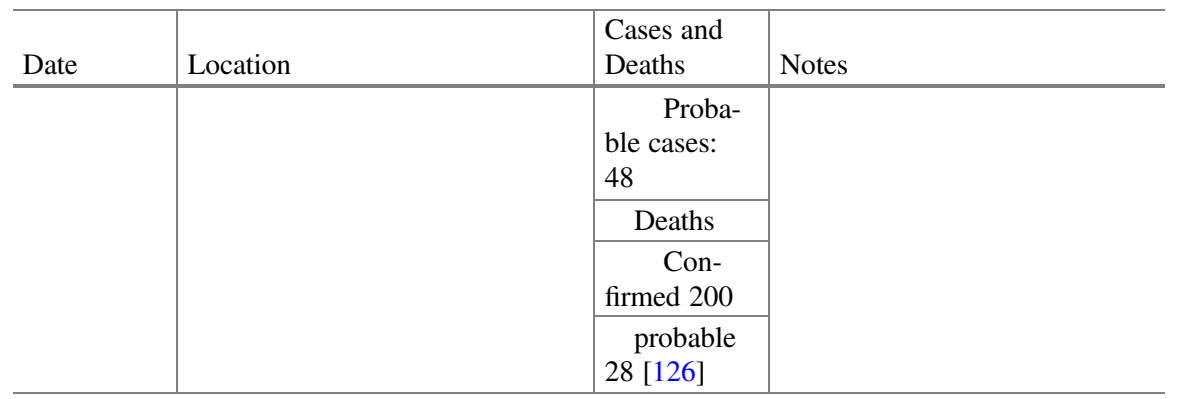

Unless otherwise noted, information obtained from the Center for Disease Control: https://www. cdc.gov/vhf/ebola/history/distribution-map.html

\section{Society, Social Determinants of Health and Ebola}

Social determinants of health are the conditions in which a person lives and grows. There is no one list of these factors, but they are generally considered to include influences such as school, (un)employment, the community where one resides, food, and transportation. The factors are driven by forces outside of one's sphere of control such as poverty and war as well as some potentially self-directed choices such as belief system and friend circle. For example, social determinants of health are a way of describing why when a 5.9 magnitude earthquake hits Haiti buildings collapse and people die and when a 5.9 magnitude earthquake and the same earthquake on Guam causes no damage. Social determinants of health significantly affected how Ebola has impacted affected countries.

\subsection{Poverty}

Poverty affects every aspect of life for most. According to World Bank data, the rate of poverty in Sub-Sahara Africa is trending downwards but is still over $40 \%$ of the population. Poverty leads to lack of education, limited medical resources, poor nutrition, and crowded living conditions. People in poverty will eat a dead animal if they find one because it may be all they have to eat. They are unlikely to seek medical care outside of traditional healers because it is all they know and can afford. They may insist on washing the bodies of the dead because their only knowledge of science are traditions passed from generation to generation. All of which contributes to the spread of Ebola. 


\subsection{War and Conflict}

Anyone who reads the history the countries that make up the peri-equatorial regional of Africa will quickly notice that the region has suffered from nearly continuous war since even before the European occupation. There are pockets of stability in the region, but conflict is a way of life for many. Conflict leads to destruction of infrastructure, fear, stress, distrust, and population displacement. Currently, an Ebola outbreak is occurring in DRC. Refugees from DRC continually flee into neighboring countries, especially Uganda. Conflict driven human movement is a means by which Ebola can be spread. No widespread outbreak of Ebola has occurred in a refugee camp, but these types of settlements are fertile soil where an outbreak could start and flourish before an alarm is raised. The Ugandan government is working with the International Federation of the Red Cross and Red Crescent Societies (IFRC), UNICEF, and the WHO collaborating to develop an Ebola emergency preparedness plan [53].

\subsection{Limited Public Health Infrastructure and Scarcity of Health Providers}

Political and economic instability across have resulted in a debilitated medical and public health infrastructure. Official data is limited, but media sources have reported that Liberia has experienced a severe shortage of trained health workers within the country. Media sources list 207 general practitioners, 18 public health specialists, 15 pediatricians, 12 surgeons, 10 obstetrician-gynecologists, 6 ophthalmologists, 8 internists, 6 dentists, 4 psychiatrists, 4 family medicine specialists, 2 orthopedic surgeons, 2 radiologists, 1 pathologist, 1 ear-nose-throat specialist, 1 veterinarian, and 1 dermatologist as comprising the entire formally trained health community (excluding nursing professionals) [3]. The CIA world factbook lists the number of physicians per 1000 people to be 0.02 for Liberia, 0.02 for Sierra Leona, 0.08 for Guinea, 0.09 in DRC, and 0.09 in Uganda [30]. Even some of these numbers are almost 10 years-old making it difficult to assess the actual situation in the region. Regardless, it is a safe conclusion that none of these countries are even close to having the recommended 1 physician per 1000 residents recommended by the WHO. Each of these countries is unique in the health care challenges it faces, and only are mentioned here because they have all been touched by Ebola.

Infrastructure development is generally associated with improved health and decreased disease burden, but this is not always the case. While lack of infrastructure such as water and sanitation is thought to lead to increased transmission. Increased connectivity via road and boat is thought to increase the risk of transmission through increased number of contacts [77]. 


\subsection{Cultural Beliefs and Practices}

One of the most fascinating aspects of Ebola occurs at the intersection of culture and public health. For generations, a mixture of traditional beliefs and mainstream religion has served as a cultural foundation in many tribal areas across Central and Western Africa. Funerary practices in these tribes are some of the most important in their belief system. It is these practices that have been exploited by the Ebola virus allowing it to spread. Exposure has been associated with attendance of funerals and contact with dead bodies in multiple countries [1, 9, 37]. As public health and medical personnel tried to curb Ebola spread, conflict has occurred. Those most at risk for Ebola suddenly felt threatened not only by the disease itself, but also by those where were trying to help as their core beliefs were suddenly targeted.

From the perspective of the health care workers trying to save lives, the cultural beliefs were generally considered as just another barrier to be surmounted. This lack of understanding between those at risk and the health care workers lead to conflict, distrust, which at times drove Ebola victims into hiding rather than seeking care. Bribes were made, bodies were stolen, aid workers were attacked, and Ebola spread. Some of the cultural beliefs common in Central and Western Africa will be discussed here with the goal of fostering cultural understanding of disease. Given the diversity of human beliefs, it is likely that future events will again put disease control against traditional beliefs.

A good starting point in cultural sensitivity is viewing an idea from the point-ofview of the other party. In the case of Ebola, it is important to understand what different groups of people believe to be the etiology of disease. Most educated health professionals view disease as an understandable biological process. Infections are caused by microbes. In the case of Ebola, it is a filovirus. In many traditional African cultures, disease is believed to be due to witchcraft [89].

Consultation with traditional healers is a common practice across Africa. In many regions traditional healers are the only locally available medical provider. Even if modern medical facilities exist, many will turn to the traditional healers first because they are more trusted, and their beliefs tend to align more closely with those of the community. There are many different traditional healing practices, sometimes traditions are passed down through generations in specific families. One description of a traditional medical ceremony in Sudan describes a medicine man and his assistants. First, ritualistic dance and chants are performed. Next the medicine man shows his spiritual power by having a large rock placed on his abdomen and broken by an ax while he remains still. Once his strength has been established, his attention can be turned to his patient. The medicine man's diagnosis is mental illness caused by evil ancestors who have returned with the purpose of tormenting the patient. Incantations are the treatment [106]. Beliefs and practices such as this are common in rural Central Africa. In these societies, illness is viewed as a disruption in the relationship between God, ancestors, and the person affected. Witchcraft, sorcery, angry ancestors, and evil spirits may all be at the root of disease and a powerful medicine man can restore the proper balance in these relationships thus curing disease [84, 91]. The 
individual customs and beliefs associated with the cause and treatment of disease is too long to be included here, but those interested in additional information should read the articles cited in this section for additional details.

Traditional healers can be a great asset to a community, but there have been unfortunate instances where they actually promoted the spread of Ebola. Some traditional healers claimed to be able to cure Ebola. Unfortunatly, their attempts at cure have been known to spread the disease to those in attendance of curative ceremonies as well as to themselves [78]. Traditional healers can also charge a significant amount of money putting a family who is already dealing with the loss of a loved one in additional financial stress [51]. Not all traditional healers seek the good of the community but instead are motivated by personal gain.

Many societies in Central Africa practice religious beliefs based on a combination of mainstream religion and ancestor worship. Occult ceremonies, secret societies, and rituals are common, and the details of these practices are often covert, only known to a small subpopulation. The ceremonies may be benign such as the one described in the preceding paragraph or may involve animal or human sacrifice $[15,65]$. While many of these practices involve sacrifice and exposure to blood no studies have been published linking these activities to Ebola transmission.

It is the traditional funerary practices that have been most closely associated with the spread of Ebola. Many Central and Western African cultures view the death ceremony as one of the most important. When people die, they must be guided to the realm of the ancestors. From this realm, ancestors are able to hear the requests and see the needs of the living family and communicate these needs to God. The living family prays directly to the ancestors. If death rights are not done correctly then instead of becoming an ancestor, the deceased may become an angry ghost which torments the family [101].

A common funerary practice in Liberia is for an elder family member to bathe the body of the deceased. It is common for mourners to touch the face and kiss the forehead of the deceased. In some traditions the spouse of the deceased continues to share a bed with the corpse until the time of burial. Another tradition involves dance. On the night prior to the funeral, men dance with the dead body while women wail. Several traditions involve sacrifice and exposure to the blood of a bull as part of their ceremony [101].

To prevent the spread of disease the Governments in Liberia and Guinea passed laws requiring safe burial teams or cremation when the number of grave sites was insufficient for the number of bodies. Numerous reports of bribing health workers responsible for collecting and properly disposing of the bodies allowed Ebola to persist in this region [50]. People stopped going to the health care facilities, and families would try to hide the cause of death from officials.

At the height of the epidemic in Sierra Leone, the number of Ebola care beds was insufficient for the number of patients. Many were transferred from facility to facility and their families were not notified. Rumors began to spread that the Ebola facilities were harvesting organs and killing people [81]. Poor communication resulted in suspicion and distrust. 
It took thousands of deaths, but finally both sides began to compromise. The government and health care workers started to work with local religious leaders and traditional healers to find solutions that would let the people honor the dead without exposing themselves. Many Muslim leaders told their followers to abstain from washing bodies until the outbreak ended. Bodies were buried with families nearby and although the could not touch the bodies prayers could be said. Burial teams started to dress corpses in clothing requested by the family and often placed requested jewelry. Once all sides compromised and started working together the epidemic was able to be contained [81].

Even if someone survives Ebola the battle is not over. There is poor understanding of disease and disease transmission. Survivors may be ostracized and shunned by their communities because there is fear that they can spread disease. Survivors have had their houses burned, families attacked, and lost their jobs due to irrational community fear. During the west African Ebola outbreak survivors were issued certificates stating that they were no longer contagious in an attempt to combat social stigma.

\subsection{Conclusion}

This is not to say that it is all gloom-and-doom in countries that have experienced Ebola outbreaks. Social determinants of health are not isolated static elements. Technology and globalization are bringing health improvements at an unprecedented rate. If one reviews data for the countries where significant Ebola outbreaks have occurred, Guinea, Uganda, DRC, South Sudan, and Liberia. All of these countries have had a decrease in infant mortality rates, decrease in maternal mortality rates, and extreme poverty rate have been steadily dropping over the last 20 years despite the presence of Ebola [46]. Anyone interested in additional information on measurable global trends, whether they be economic, or health based is encouraged to visit Gapminder (www.gapminder.org).

Not every country that faces Ebola descends into a public health crisis. In July 2015 multiple cases of EVD were diagnosed in Lagos, Nigeria. Lagos is a densely populated city and the capital of Nigeria. The Nigerian ministry of health was able to rapidly contain the situation before a full-scale epidemic began. The Nigerian government had access to trained health care providers able to do contact tracing, able to mobilize a rapid efficient response, and worked closely in cooperation with the WHO to implement standardized epidemiologic practices. The epidemic in Nigeria was halted before it was able to start [40]. 


\section{Ebola in the Technology Era}

\subsection{Screening}

The concept of quarantine was first developed in the fourteenth century to control the spread of plague [24]. Quarantine is a required separation of incoming people or animals prior to mixing with the local population with the goal of preventing the spread of disease. It is one of the oldest and most effective public health measures, but very unpopular with those whose movements are restricted by quarantine.

Recently, Kaci Hickcox, a nurse volunteering in Sierra Leone returned to the US. She possibly had been exposed to the Ebola virus. Ms. Hickcox was placed on a mandatory home quarantine of 21 days, but she defied the quarantine order and proceeded with her day-to-day activities [98]. In reality, she was at very low risk for developing the disease, and there was essentially no risk for widespread Ebola transmission in the US, but her unwillingness to comply with the quarantine brought attention to many public issues surrounding quarantine. Specifically, the conflict between individual civil liberty and the well-being of the general public [127]. Since 1944 when quarantine laws were first written technology has expanded drastically. Surely there exists a technology that allows us to abolish the antiquated quarantine system.

Whether an intentional act of terrorism or through accidental contagion spread, travelers pose a significant threat to homeland security. Various measures have been attempted to try and identify sick travelers with the goal of limiting epidemic spread. The following is a discussion of currently available boarder control measures aimed at preventing the spread of disease, and evaluation of the effectiveness of these measures, and a discussion of technologies that may be of utility in the future in preventing cross-border Ebola spread.

\subsubsection{Pandemic Vulnerability and Travel}

Two-point-five million people fly in or out of the United States every day [44] and an estimated one-million more per day cross via land and sea [16]. With millions of border crossings daily, transmission of communicable disease between remote locations is inevitable. The vast majority of communicable diseases spread by travelers are upper respiratory viruses such as the common cold or influenza. Generally, these are self-limited illnesses with few long-term consequences. Every few years though, something new with greater lethality emerges and threatens the security of the US travelers, their contacts, and the broader population at home. Ebola, Severe Acute Respiratory Syndrome (SARS), and even the relatively benign Zika virus have made media headlines with travelers seen as potential harbingers of disease. 
Another factor that must be taken into account is the increasing population density and urbanization. The United Nations (UN) predicts that $65 \%$ of all people will live in cities by the year 2050 [109]. A megacity is defined as an urban population of over ten million people. The first to reach megacity status was New York City in the 1930's [31]. By 2018, the megacity count rose to 37 [36]. Large numbers of people in a small area constitute a vulnerability when looking at epidemic risk assessment. A single ill traveler arriving to a megacity has the potential to start a local chain of infection that could rapidly spread to millions.

With the widespread availability and affordability of trains, planes, automobiles, buses, and boats it is easy for microbes as well as humans to travel rapidly across the globe. Travel provides individual freedom for pleasure and commerce but, at the expense of national security. Small disease outbreaks are continually occurring across the globe. Multiple international monitoring systems are in effect and the Center for Disease Control (CDC) has issued official recommendations for travel restrictions for persons with higher-risk exposure to communicable diseases of public health concern [114]. Briefly, these guidelines state that a person who meets the following criteria will have their travel restricted [114]:

Be known or likely infectious with, or exposed to, a communicable disease that poses a public health threat AND meet one of the following three criteria:

1. Be unaware of diagnosis, noncompliant with public health recommendations, or unable to be located.

OR

2. Be at risk for traveling on a commercial flight, or internationally by any means. OR

3. Travel restrictions are warranted to respond effectively to a communicable disease outbreak or to enforce a federal or local public health order.

While the above criteria may be the best legally available option, it leaves a multitude of holes by which a person with a communicable illness could slip into a US city and start a new epidemic. Ideally, additional layers of protection would allow potentially ill travelers to be identified and detained prior to entry to the United States.

\subsubsection{Ebola, Travel, and Homeland Security}

An infectious agent can travel across the globe in $24 \mathrm{~h}$ if spread via airplanes [14]. This has important implications for those trying to prevent disease from spreading. Land and boat entry into the United states present other challenges. The sheer number of people crossing by land on a daily basis makes any screening difficult. Boat traffic can also present unique screening challenges. A cruise boat, for example, may arrive with thousands of people who all debark within a short period of time. Though screens are impractical in these situations. Even if screening technology was employed allowing security agents to detect fever there are so many causes of fever that timely interpretation of the data would be difficult. With so much international travel occurring, there is a continual search for ways to 
improve screening for ill travelers with the goal of preventing importation of disease. Many different methods have been tried, most centered around a specific pandemic rather than continual monitoring. None have had great success. These methods have included entry-screens, exit-screens, and post-entry monitoring.

\subsubsection{Point-of-Entry Screening for Ill Travelers}

The US division of Quarantine is not only authorized, but required to identify and detain anyone entering the country with actual or suspected diphtheria, any viral hemorrhagic fever including Ebola, cholera, tuberculosis, small pox, plague, novel influenza strains or yellow fever [22, 94, 95]. In theory, this is an excellent regulation, but how can millions of travelers be efficiently screened and detained if needed?

After the outbreak of SARS in 2003 many countries starting using boarder screening to try to identify possibly ill people in hopes of limiting spread of infectious disease, others jumped on board after the 2009 H1N1 influenza pandemic. The issue then resurged in the wake of the 2014 Ebola outbreak in West Africa. As with many things, there must be an understanding of the costs, potential benefits and effectiveness of programs aimed at preventing a possible public health disaster.

An article by the CDC, published around the same time as the article recommending travel restriction for high-risk individuals, concludes that border screens are expensive and not effective in preventing the spread of disease [100]. While point-of-care screens are not yet considered an effective means of controlling certain biosecurity threats, progress is being made.

\section{Temperature Screens}

Temperature screens have been developed with the goal of identifying people with fever. What happens when a fever is detected depends on where a person is traveling to and from, and the current state of outbreaks occurring in the world. There are several types of temperature readers including ear gun thermometers, full body infrared scanners, and hand-held infrared thermometers [68]. None of these methods is highly effective and most screening devices can be fooled with minimal training and effort. Once study found that thermal screens were only about $70 \%$ effective in detecting fever. The authors of this study concluded that temperature screens were ineffective in identifying ill travelers [64].

The European Center for Disease Control (ECDC) has also investigated the feasibility of using temperature screens to identify ill travelers and came to similar conclusions. This report was done during the Ebola of 2014 and geared towards diagnosing travelers potentially infected with Ebola. They estimate that even under ideal conditions $20 \%$ of symptomatic illness would be missed due to low sensitive of temperature devices [41]. Additionally, it was concluded that those intentionally trying to mask their temperature could easily do so and that those who had not developed symptoms would be missed by the screen. 
Even if fevers screens were accurate and difficult to manipulate that would still be a poor screening measure. First of all, with many illnesses including chicken pox, flu, the common cold and countless others, people can be contagious before a fever starts. It is not yet known if an infected person can spread Ebola before symptoms begin. Secondly, not all fevers indicate an infectious disease. Fevers can be due to drug reactions, blood clots, and even cancer. Third, not everyone reacts to an infection the same way. Some people naturally tend to have fever and others tend not to. One expression commonly taught in medical schools across the US is, "the older the colder". This is a reminder to students that elderly patients may never have a fever even if they are extremely ill with an infectious disease. Lastly, what determines what constitutes a fever? The medical field defines fever as a temperature of 38 degrees Celsius (100.4 F) or higher. Are these same numbers valid for travelers or should different cut offs be used? While temperature screens may have their place in emergency settings, they are far from an ideal way of detecting an ill passenger and the day to day use of temperature screens is not generally considered an effective means of identifying ill travelers.

\section{Pre-departure Screens}

When foreign agencies are cooperative screening may be done prior to departure. Exit screening was done during the Ebola outbreak of 2014 for travels from West Africa to the United States. The goal of exit screening is to identify those potentially infected with a specific disease and prevent them from departing for the United States until they can be medically cleared. The CDC considers this to be one of the more effective forms of preventing disease importation to the United States [26]. Departure screens are not routinely used except during times of known outbreaks.

During the 2014 West African Ebola outbreak exit screening measures were implemented. The general process used for screening during the outbreak was as follows. Travelers were instructed to arrive earlier than they normally would for their travel due to increased processing times. General instructions to travelers instructed them to postpone travel if they were ill. In addition to the regular airport screening, all travelers were required to have their temperature taken and fill out a "Traveler Public Health Declaration". Travelers who were febrile or considered at risk based on the answers to their health declaration forms were detained and their travel delayed [124]. During the Ebola outbreak the WHO provided resources for predeparture screening that were detailed yet used easy-to-follow language and including flow charts for those performing the screen. Basic information on Ebola and its symptoms so that the illness was more well understood and the disease symptoms familiar. Directions for using personal protective equipment for those performing the screening. Written tools and the public health declaration form were provided. Additional resources included a data collection log and a traveler information card that could be distributed to travelers [124]. 
The Ebola screening was done in two steps, a primary screen and a secondary screen. The primary screen included three questions: (1) Is the traveler febrile?; (2) Is the traveler demonstrating symptoms of Ebola?; and (3) Has the traveler marked "yes" to any questions on the health declaration form? An affirmative response to any of these questions resulted in secondary screening. Secondary screening involved a public health interview and filling of the secondary health screen form, repeat temperature measurement preferably with an accurate thermometer, and focused medical exam. If the secondary screen found a temperature $<101.5$, no risk factors for Ebola in the public health interview, and no symptoms of Ebola on the public health interview they were allowed to proceed to check-in. If the above criteria were not met, check-in was denied until health clearance could be obtained [124].

This strategy was considered effective. The limitations include the time and money required to implement the program, frustrating travel delays for travelers, and the inability to identify illnesses other than Ebola or similar diseases. Its usefulness is limited to known and identified epidemics. This strategy will likely continue to be used in future outbreaks to prevent exportation of disease [41].

Temperature screens have been used during five epidemics to date, dengue, SARS, Ebola, and Influenza during both the entry and exit process. Screening for fever in Taiwan entry points during a dengue outbreak was reported to be effective. One research study reports that $45 \%$ of imported dengue cases were able to be identified through airport screening [71]. During the SARS outbreak, Singapore entry points screened 400,000 people and identified no cases, Canada entry points screened 6.4 million people and identified no cases, and Hong Kong entry points screened 35.6 million people identifying only two cases of SARS [41]. Fever screening was used during the 2009-2010 influenza pandemic and even with a low threshold for defining fever was found to have a sensitivity in the $4.5 \%$ range. Exit screening done in West Africa during the Ebola outbreak identified fever in 77 out of 36,000 travels screened. Of these, none had Ebola [25]).

\section{Active Monitoring}

Active monitoring is another technique that can be used in preventing disease spread within Ebola naive countries such as the United States. It involves allowing a traveler freedom to come into the US, freedom from quarantine, but also allows health authorities to monitor the health status of potentially infected people. If someone begins to develop symptoms then measures can be taken to isolate, diagnose, and treat the ill person. This method is best applied to those who are reliable and at low risk for developing illness.

There has not been much experience with widespread use of active monitoring systems with the exception of the 2014 Western Africa Ebola outbreak. During this outbreak, travelers from Liberia, Sierra Leone, and Guinea to the US were given CARE (Check And Report Ebola) kits upon arrival to the US [23]. CARE kits 
provided resources to travelers from Ebola affected countries. Travelers were given information on the signs and symptoms of Ebola, educated on the basic pathophysiology of Ebola, provided a thermometer with detailed use instructions and given a cell phone to ease the communication process. Travelers were allowed to travel freely but were required to check in with public health officials daily. During these check-ins, -health reports were given including the development of any new symptoms, and daily temperature readings for 21 days. Ebola has a highly variable incubation period. Twenty-one days was the longest interval between exposure and disease presentation to have been reported accounting for its use in both CARE packages and quarantine [125].

While the CDC coordinated active monitoring programs, the programs were managed at the state level. All states eventually participated, but with varying start dates. New York, Pennsylvania, Maryland, Virginia, New Jersey, and Georgia were those to first initiate the program. Seventy percent of travelers from West Africa enter through these states making them logical starting points for the program [21].

After much legal debate and unwanted publicity, Ms. Hickcox mentioned in the introduction, eventually went into active monitoring program which restored most of her personal freedoms while at the same time protecting public interests.

\subsubsection{Conclusion}

Currently available technology is considered insufficient to prevent entry of ill individual into Ebola naive countries. The general public continues to demand protection of civil liberties that include the freedom to travel and protection of privacy. Despite recommendations by the CDC, it is difficult to identify an ill traveler either before a person embarks for the US or at the point-of-entry. Post entry monitoring of reliably low risk travels is a socially acceptable alternative to quarantine and considered reliable although not widely tested.

Screening technologies such as infrared screens may not be considered useful on a daily use basis but may prove of utility under certain circumstances such as an active Ebola outbreak. As research continues, technology advances, and better models to study patterns of disease spread are developed, new methods of pointof-entry biosecurity are sure to emerge.

\subsection{Bioterrorism}

Bioterrorism is the intentional spread of disease with the goal of destabilizing an opposing group. It is thought to have roots extending back to at least $1320 \mathrm{BCE}$ when the Hittites used infected sheep to spread infection and destabilize their opponents [108]. Since that time, technology has improved and along with it the threat of bioterrorism has augmented. 
The Center for Disease Control (CDC) divides bioterrorism agents into three separate categories A, B, and C. Category A agents are those which are considered to be of highest risk. Characteristics group A pathogens are, easy transmission, high mortality rate, protentional for social disruption, and require special action. Category $\mathrm{B}$ agents are of concern, but considered to have a lower potential for disease than those in group A. This category is comprised of pathogens that are moderately easy to spread, have moderate morbidity, low mortality and require specific diagnostic and surveillance tools. Group C are agents of some concern. This group is made of pathogens that are easily available, easy to produce and disseminate, and potentially have significant medical and public health implications. Emerging infections also fall within group $\mathrm{C}$ pathogens. Ebola is considered to be a high threat level A biothreat [19].

\subsubsection{Ebola: Potential in Bioterrorism}

Bioweapons are at least as large a threat to homeland security as are traditional weapons. Biological weapons are attractive to potential terrorists because they are relatively inexpensive to manufacture, easy to encounter, and easy to distribute [6].

In 1975 the Biological Weapons Convention went into effect. It has been signed by 180 countries and prohibits the development of biological agents for the purpose of warfare. Unfortunatly, terrorists fail to abide by this convention, and it is rumored that even some of the countries that signed the convention document continue to engage in clandestine research into biological agents for warfare.

Characteristics of a pathogen with bioterrorism potential are those with consistent disease induction and progression, high infectivity, are easily transmissible between people, are difficult to diagnose, and have a high mortality rate [49]. It is also important that the pathogen be stable during production, storage, and distribution [6]. Lack of immunity in the targeted population and diseases that are difficult to diagnoses are also attractive to would-be terrorists. Ebola possesses many of these characterizes.

Ebola possesses many features of an ideal bioterrorism weapon. In the early stages, Ebola presents as an acute viral illness. By the time clinical features unique to Ebola infection have developed, it is likely that the illness will already have be transmitted to others. Particularly vulnerable are those caring for infected patients including family members and health care workers. Despite being limited to transmission through body fluids, Ebola is highly contagious. Ebola has a high mortally rate and is attractive to terrorists because there is already widespread fear associated with Ebola infection. Reston virus, a non-human pathogen in the Ebola family, can be transmitted. There is concern that with genetic manipulation EVD could be transformed into an airborne illness and distributed as a bioterrorism weapon [20].

Ebola is one of the many pathogens that could potentially be converted into a biological weapon. Preparedness plans at the local, state, and national level all include sections applicable to Ebola. All hospitals in the nation have received 
training on Ebola identification and response. Continued vigilance and repetitive training sessions are required to ensure that should Ebola be used as a biological weapon, it will be rapidly identified and contained.

\subsubsection{Conclusion}

Ebola virus is an agent that could be used as a bioterrorism agent. It is deadly, can result in long term infection in survivors, and non-specific clinical presentation make it an attractive choice for would be terrorists. Also, for many people, the word Ebola creates fear out of proportion to the actual risk of disease. This visceral reaction and exaggerated fear make Ebola a tempting agent. On the other hand, the lack of airborne spread and existence of effective vaccine (even if not licensed) are deterrents to its use.

\section{Ebola and Environmental Degradation}

It is impossible to know with certainty when the first Ebola infection occurred. Most likely it was in a remote African jungle and those infected died without a diagnosis other than that provided by the local traditional healer. What can be said with certainty is that the outbreaks are occurring with more frequency. No one knows with certainty why this is. Hypothesis tend to center around issues of environmental degradation in association with increased population mobility. Increasing population, global warming, and continued human encroachment into forested areas have been put forth as potential contributing factors.

\subsection{Human Population Expansion}

Increasing population is theorized to be contributing to the increasing frequency of Ebola outbreaks. Increasing populations, particularly in developing countries, tend to lead to congesting living conditions and rapid disease spread, but this would not explain how the index case in an outbreak becomes infected. Experts opinion often lists expanding population as contributing to the Ebola outbreak, and intuitively it is credible, but there is little in the way of direct evidence to support this theory. Literally hundreds of studies have been conducted on Ebola since the 2014 outbreak, but none directly addresses the relationship between population growth in Africa and increasing frequency of Ebola outbreaks. It is likely that the impact of increasing human populations in endemic areas will not be fully understood until the reservoir of Ebola has been determined. 
What we can say with certainty is that once started, Ebola spreads more quickly than it did in the past and is killing more people. Population level research on Ebola has yielded interesting results. For a start, risk of Ebola infection has been associated with a higher level of education [73, 111]. Lower risk for acquisition of Ebola at the population level has been associated with urban residence, households with no or low-quality sanitary system, and married men in blue-collar professions in the 2014 outbreak in West Africa [73].

Other studies have found different results when examining the interplay between population dynamics and the emergence of Ebola. For example, in contrast to the study by Levy \& Odoi, Ebola transmission has been positively correlated with population density, and proximity to Ebola treatment centers in other investigations [42]. Another study found that $84.6 \%$ of people who tested positive for Ebola cases lived within a $3-\mathrm{km}$ of roads connecting rural towns and densely populated cities [75].

Basic public health principles hold that increasing population density allows infectious disease to spread more quickly, but it is unclear what the impact is on the emergence of Ebola. It is safe that there is a relationship between population density, population distribution, and Ebola but the exact nature of that relationship remains elusive.

\subsection{Climate Change}

Climate change has been cited by mass media sources as the source of emerging disease such as Ebola. Elevated atmospheric temperature have been associated with the development of EVD, but then so have low temperatures [42]. There does appear to be a relationship between Ebola and temperature, but the character of that relationship is not clear. Ebola virus is sensitive to high temperatures so intuitively, higher temperatures would not create a more active form of the virus. What may change is the human response to higher temperatures. When it is hot, people sweat more, drink more, and may wear different clothing. It may be that the human response to hot weather is responsible for the noted difference rather than changes in viral activity. It is also possible that temperature changes correlate with other phenomena such as rain storms and that rain, or the response of vegetation to rain somehow impacts the emergence of Ebola.

Climate change, whether due to human activities or natural climatic cycles will change patterns of disease across the globe. How changing weather patterns may affect the distribution and frequency of Ebola cases remains to be seen. Possibly once the reservoir of Ebola virus has been discovered scientists can predict with greater certainty how climate change will impact the emergence of Ebola. 


\subsection{Environmental Encroachment}

It is also postulated that Ebola is occurring with greater frequency due to increasing human activities within previously untouched natural areas. At least one study has linked deforestation to EVD outbreaks [90]. Again, there are limited studies confirming this idea, but logic does suggest that it would be true.

Expert opinion, and the mass media purport that the increasing frequent outbreaks of Ebola are due to environmental encroachment [85]. As roads are build, forests are cut, and mineral resources exploited humans are in more intimate contact with the forest and its inhabitants including the reservoir for Ebola. The reservoir is unknown, but it is probably found in African jungles. A study looking at vegetation cover, population density and incidence of Ebola found that vegetation was protective until the population reached 200 people per square $\mathrm{km}$. At this population density vegetation became associated with and increase incidence of EVD [115]. There is a relationship between environmental encroachment and the emergence of Ebola, but until the reservoir is found it will be difficult to determine the exact nature of this relationship.

\section{Future Directions}

\subsection{International Collaboration}

The frequency of Ebola outbreaks has been increasing. International collaboration is essential to better understand how and why this is occurring. Traditional tribal regions do not always follow country lines and both official and unofficial border crossing are common. Contact tracing is essential for containment of Ebola outbreaks requires countries to coordinate as people cross borders. Epidemiological evaluation and experience in treating the disease also require a global rather than country approach. The study of Ebola requires systematic evaluation and intercountry coordination to most effectively predict outbreaks and limit their spread once they do occur.

The global community would also benefit from international standards for diagnosis, prevention, and treatment. Luckily, framework already exists for this collaboration, at least in times of epidemics with pandemic potential. The International Health Regulations (IHR) agreement is legally binding accord signed by 196 countries. It stipulated that these countries must act to contain the threat if a Public Health Emergency of International Concern (PHEIC) is declared by the WHO director general. A PHEIC was declared in August 2014 in response to the Ebola outbreak in West Africa [13]. 
The IHR helps to ensure that an appropriate global health response will be made once a public health disaster is well underway. Intervention at this level will help curb progression of the disaster. Along this same line of thinking, mitigation and preparedness efforts are needed prior to development of a public health disaster. If a PHEIC is declared, then local measures have failed. Improved regional collaboration is needed to help minimize the impact of Ebola in the region.

\subsection{Development of Health Care Infrastructure in At-Risk Countries}

Many countries at risk for outbreaks of EVD would benefit from bolstering of their public health and medical programs. Outside assistance is a starting point, but capacity building is required for long term solutions. In countries with weak public health infrastructure international efforts need to focus on programs to develop a sustainable public health system. The challenges are considerable particularly in areas of chronic conflict, but progress has already been made and with continued support will continue into the future. A basic public health infrastructure will help contain Ebola as well as whatever threat comes next.

\subsection{Public Education}

When an Ebola outbreak hits the general public needs to be educated on how to respond. If Ebola preparedness is part of the local education, then lives can be saved. The public can help with surveillance efforts. This would require the population to trust the public health community, believe that their input is useful, and that they be trained to recognize potential Ebola in the community.

Public health education can also assist with limiting spread if an outbreak does occur. This education can be provided through schools, community outreach campaigns, or religious institutions. The education does not need to be complex, just consistent, concise, true, and culturally appropriate.

\section{Conclusion}

Outbreaks of EVD have been occurring with increasing frequency. Thousands have died and thousands more have been lives have suffered because of the disease. The disease is highly fatal, but even more insipid, it exploits traditional ceremonies and death-rights as a means of spread. Poverty, both at personal and national level has resulted in an infrastructure ill-equipped to deal with events such as Ebola. 
Overcrowding promotes transmission and lack of financial incentives have delayed vaccine development. Despite the barriers, EVD is slowing being more well understood, thousands of research articles have been published, and guidelines for every aspect of the disease have been published by the WHO, CDC, or other government level organizations. Progress is being made.

\section{References}

1. Agua-Agum J, Ariyarajah A, Aylward B, Bawo L, Bilivogui P, Blake I, Yoti Z (2015) Esposure patterns driving Ebola transmission in West Africa: a retrospective observational study. PLoS Med. https://doi.org/10.1371/journal.pmed.1002170

2. Assessment of the Risk of Ebola Virus Transmission from Bodily Fluids and Fomites (2007) J Infect Dis 196(S-2):S142-S147

3. Ballah Z (2016) Liberia's 4.5 million population has only 298 medical doctors. Retrieved December 6, 2018, from The Bush Chicken: https://www.bushchicken.com/liberias-4-5-mil lion-population-has-only-298-medical-doctors/

4. Baron R, McCormick J, Zubeir O (1983) Ebola virus disease in southern Sudan: hospital dissemination and intrafamilial spread. Bull World Health Organ 61(6):997-1003

5. Bausch D, Towner J, Dowell S, Kaducu F, Lukwiya M, Sanchez A et al (2007) Assessment of the risk of Ebola virus transmission from bodily fluids and fomites. J Infect Dis 196(Suppl 2): S142-S147

6. Beeching N, Dance D, Miller A, Spencer R (2002) Biological warfare and bioterrorism. BMP 324:336

7. Beeching N, Fenech M, Fletcher T, Houlihan C (2018) Ebola virus infection. BMJ Best Pract. Retrieved December 5, 2018, from https://bestpractice.bmj.com/topics/en-us/1210/pdf/1210. pdf

8. Bonwitt J, Dawson M, Kandeh M, Ansumana R, Sahr F, Brown H, Kelly A (2018) Unintended consequences of the Bushmeat Ban in West Africa during the 2013-2016 Ebola virus disease epidemic. Soc Sci Med 200:166

9. Brainard J, Hopper L, Pond K, Edmunds K, Hunter P (2016) Risk factors for transmission of Ebola or Marburg virus disease: a systematic review and meta-analysis. Int $\mathbf{J}$ Epidemiol 45:102-116. https://doi.org/10.1093/ije/dyv307

10. Brandt A, Oria O, Kallon M, Bazzano AN, Alessandra N (2017) Infant feeding policy and programming during the 2014-2015 Ebola virus disease outbreak in Sierra Leone. Glob Health: Sci Pract 5(3):507-515

11. Bray M, Mahanty S (2003) Ebola hemorrhagic fever and septic shock. J Infect Dis 188:1613-1617

12. Breman J, Heymann D, Lloyd G, McCormick J, Miatudila M, Murphy F et al (2016) Discovery and description of Ebola Zaire virus in 1976 and relevance to the West African epidemic during 2013-2016. J Infect Dis 214(suppl 3):S93-S101

13. Briand S, Bertherat E, Cox P, Formenty P, Kieny M-P, Myhre J et al (2014) The international Ebola emergency. N Engl J Med 371:1180-1183

14. Brownstone S (2013) Outbreak! Watch how quickly an epidemic would spread across the world. Retrieved from Fast Company: https://www.fastcompany.com/3023416/outbreakwatch-how-quickly-an-epidemic-would-spread-across-the-world

15. Bukuluki P, Mpyangu C (2014) The African conception of sacrifice and its relationship with child sacrifice. Int Lett Soc Humanist Sci 30(1):12-21

16. Burearu of Transportation Statistics (n.d.) United States Department of Transporation. Retrieved from Border Crossing/Entry Data: https://www.bts.gov/content/bordercrossingentry-data 
17. Bwaka M, Bonnet M, Calain P, Colebunders R, De Roo A, Guimard Y, Van den Enden E (1999) Ebola hemorrhagic fever in Kikwit, Democratic Republic of the Congo: clinical observations in 103 patients. J Infect Dis 179(Suppl 1):S1-S7

18. CDC (2015) Interim guidance for healthcare workers providing care in West African countries affected by the Ebola outbreak: limiting heat burden while wearing personal protective equipment (PPE). Retrieved December 6, 2018, from https://www.cdc.gov/vhf/ebola/hcp/ limiting-heat-burden.html

19. CDC (2018) Retrieved December 1, 2018, from Center for Disease Response: https://emer gency.cdc.gov/agent/agentlist-category.asp

20. Cenciarelli o, Gabbarini V, Pietropaoli S, Malizia A, Tamburrini A, Ludovici G, Bellecci C (2015) Viral bioterrorism: learning the lesson of Ebola virus in West Africa. Virus Res 210:318-326

21. Center for Disease Control and Prevention (2014a) CDC announces active post-arrival monitoring for travelers from impacted countries. Retrieved from CDC: https://www.cdc. gov/media/releases/2014/p1022-post-arrival-monitoring.html

22. Center for Disease Control and Prevention (2014b) Enhanced Ebola screening to start at five U.S. airports and new tracking program for all people entering U.S. from Ebola-affected countries. Retrieved April 10, 2018, from CDC: https://www.cdc.gov/media/releases/2014/ p1008-ebola-screening.html

23. Center for Disease Control and Prevention (2014c) History of quarantine. Retrieved from CDC: https://www.cdc.gov/quarantine/historyquarantine.html

24. Center for Disease Control and Prevention (2014d) Enhanced Ebola screening to start at five U.S. airports and new tracking program for all people entering U.S. from Ebola-affected countries. Retrieved April 10, 2018, from CDC: https://www.cdc.gov/media/releases/2014/ p1008-ebola-screening.html

25. Center for Disease Control and Prevention (2014e) History of quarantine. Retrieved from CDC: https://www.cdc.gov/quarantine/historyquarantine.html

26. Center for Disease control and Prevention (2015) Protecting borders: the road to zero. Retrieved from CDC: https://www.cdc.gov/about/ebola/protecting-borders.html

27. Cherfow D, Nath A, Suffiredini A, Danner R, Reich D, Bishop R et al (2016) Severe meningoencephalitis in a case of Ebola virus disease: a case report. Ann Intern Med 165 (4):301

28. Christie A, Davies-Wayne G, Cordier-Lassalle T, Blackley D, Laney A, Williams D et al (2015) Possible sexual transmission of Ebola virus - Liberia, 2015. Morb Mortal Wkly Rep 64 (17):479

29. Chughtai A, Barnes M, MacIntyre C (2016) Persistence of Ebola virus in various body fluids during convalescence: evidence and implications for disease transmission and control. Epidemiol Infect 155(8):1652-1660

30. CIA World Factbook (n.d.) Retrieved Decembwr 6, 2018, from https://www.cia.gov/library/ publications/the-world-factbook/fields/2226.html

31. Cox W (2017) The world's ten largest megacities. Retrieved from The Huffington Post: https:// www.huffingtonpost.com/wendell-cox/the-worlds-ten-largest-me_b_6684694.html

32. de Greslan T, Billhot M, Rousseau C, Mac Nab C, Karowski L, Cournac J, Cellarier G (2016) Ebola virus-related encephalitis. Clin Infect Dis 63(8):1076-1078

33. De Nys H, Kingebeni P, Keita A, Butel C, Guillaume T, Villabona-Areana C-J, Peeters M (2018) Survey of Ebola viruses in frugivorous and insectivorous bats in Guinea, Cameroon, and the Democratic Republic of the Congo, 2015-2017. Emerg Infect Dis. https://doi.org/10. 3201/eid2412.180740

34. Dean N, Halloran M, Yang Y, Longini I (2016) Transmissibility and pathogenicity of Ebola virus: a systematic review and meta-analysis of household secondary attack rate and asymptomatic infection. Clin Infect Dis 62(10):1277-1286. https://doi.org/10.1093/cid/ciw114

35. Deen G, Broutet N, Xu W, Knust B, Sesay F, McDonald S et al (2017) Ebola RNA persistence in semen of Ebola virus disease survivors - final report. N Engl J Med 377(15):1428-1437. https://doi.org/10.1056/NEJMoa1511410 
36. Demographia World Urban Area (2018) Demographia world urban areas: 14th annual edition. Retrieved from http://demographia.com/db-worldua.pdf

37. Dietz P, Jambai A, Paweska J, Ksiazek T (2015) Epidemiology and risk factors for Ebola virus disease in Sierra Leone - 23 May 2014 to 31 January 2015. Clin Infect Dis 61:1648-1654. https://doi.org/10.1093/cid/civ568

38. Ebola (2017a) Retrieved December 1, 2018, from Center for Disease Control: https://www. cdc.gov/vhf/ebola/history/2014-2016-outbreak/case-counts.html

39. Ebola (2017b) Retrieved December 1, 2018, from Center for Disease Control: https://www. cdc.gov/vhf/ebola/history/2014-2016-outbreak/index.html

40. Ebola in Nigeria and Senegal: stable - for the moment (n.d.) Retrieved December 7, 2018, from WHO: https://www.who.int/csr/disease/ebola/ebola-6-months/nigeria-senegal/en/

41. European Center for Disease Control and Prevention (2014) Infection prevention and control measures for Ebola virus disease. Retrieved April 10, 2018, from https://ecdc.europa.eu/sites/ portal/files/media/en/publications/Publications/Ebola-outbreak-technicalreport-exit-entryscreening-13Oct2014.pdf

42. Fang L-Q, Yang Y, Jiang J-F, Yao H-W, Kargbo D, Jia B-G et al (2016) Transmission dynamics of Ebola virus disease and intervention effectiveness in Sierra Leone. Proc Natl Acad Sci 112:4488-4493

43. Faye O, Andronico A, Faye O, Salje H, Boëlle P, Magassouba N et al (2015) Use of viremia to evaluate the baseline case fatality ratio of Ebola virus disease and inform treatment studies: a retrospective cohort study. PLoS Med 12(12):e1001908. https://doi.org/10.1371/journal. pmed.1001908

44. Federal Aviation Administration (2017) Air trafic by the numbers. Retrieved from FAA: https://www.faa.gov/air_traffic/by_the_numbers/

45. Feldmann H, Geisbert T (2011) Ebola haemorrhagic fever. Lancet 377:849-862

46. Gapminder (n.d.) Retrieved December 6, 2018, from www.gapminder.com

47. Glynn F, Bower H, Johnson S, Turay C, Sesay D, Mansaray S et al (2018) Variability in intrahousehold transmission of Ebola virus, and estimation of the household secondary attack rate. J Infect Dis 217:232-237

48. Goldstein T, Anthony S, Gbakima A, Bird B, Bangura J, Tremeau-Bravard A, Mazet J (2018) The discovery of Bombali virus adds further support for bats as hosts of ebolaviruses. Nat Microbiol 3:1084-1089

49. Green M, LeDuc J, Cohen D, Franz D (2018) Confronting the threat of bioterrorism: realities, challenges, and defensive strategies. Lancet Infect Dis. https://doi.org/10.1016/S1473-3099 (18)30298-6

50. Guion P (2014) Retrieved from wired news: https://news.vice.com/en_us/article/vbn87x/fam ilies-in-liberia-are-paying-bribes-for-false-certificates-over-ebola-deaths

51. Hewlett B, Amola R (2003) Cultural context of Ebola in northern Ugands. Emerg Infect Dis 9 (10): 1242-1248

52. Hunt L, Gupta-Wright A, Simms V, Tamba F, Knott V, Tamba K et al (2015) Clinical presentation, biochemical, and haematological parameters and their association with outcome in patients with Ebola virus disease: an observational cohort study. Lancet Infect Dis 15 (11):1292-1299

53. IFRC (n.d.) Emergency Plan of Action (EPoA) Uganda: Ebola preparedness. Retrieved December 6, 2018, from https://reliefweb.int/sites/reliefweb.int/files/resources/ MDRUG041do1.pdf

54. Infection Prevention and Control Recommendations for Hospitalized Patients Under Investigation (PUIs) for Ebola Virus Disease (EVD) in U.S. Hospitals (2018) Retrieved December 6, 2018, from https://www.cdc.gov/vhf/ebola/clinicians/evd/infection-control.html

55. Information note: Ebola and food safety (2014) Retrieved December 6, 2018, from World Health Organization: information note: Ebola and food safety

56. Interim advice on the sexual transmission of the Ebola virus disease (2016) Retrieved December 6, 2018, from WHO: https://www.who.int/reproductivehealth/topics/rtis/ebolavirus-semen/en/ 
57. Interim Guidance for Management of Survivors of Ebola Virus Disease in U.S. Healthcare Settings (2018) Retrieved December 6, 2018, from Center for Disease Control: https://www. cdc.gov/vhf/ebola/clinicians/evaluating-patients/guidance-for-management-of-survivorsebola.html

58. Jacobs M, Rodger A, Bell D, Bhagani S, Cropley I, Filipe A, Gifford R (2016) Late Ebola virus relapse causing meningoencephalitis: a case report. Lancet 388(10043):498-503. https:// doi.org/10.1016/S0140-6736(16)30386-5

59. Jagadesh S, Sevalie S, Fatoma R, Sesay F, Sahr F, Faragher B, Scott J (2018) Disability among Ebola survivors and their close contacts in Sierra Leone: a retrospective case-controlled cohort study. Clin Infect Dis 66(1):131

60. Janvier F, Foissaud V, Cotte J, Aletti M, Savini H, Cordier P, Sagui E (2016) Monitoring of prognostic laboratory markers in Ebola virus disease. J Infect Dis 213(6):1049

61. Jaxx N, Davis K, Geisbert T, Vogel P, Jaxx G, Topper M, Jahrling P (1996) Lethal experimential infection of rhesus monkeys with Ebola-Zaire (Mayinga) virus by the oral and conjunctival route of exposure. Arch Pathol Lab Med 120(2):140

62. Jones M, Schun A, Amman B, Sealy TK, Zaki S et al (2015) Experimental inoculation of Egyptian Rousette bats (Rousettus aegyptiacus) with viruses of the ebolavirus and Marburgvirus genera. Viruses:3420-3442

63. Kadanali A, Karagoz G (2015) An overview of Ebola virus disease. North Clin Istanbul 2:81-85. https://doi.org/10.14744/nci.2015.97269

64. Kamiya K, Nishiura H (2011) Some airports have a new security routine: taking your temperature. BMC Infect Dis 11:111. Retrieved from https://bmcinfectdis.biomedcentral. com/articles/10.1186/1471-2334-11-111

65. Kenan J (1997) The worship of God in African traditional religion a Nigerian perspective. Retrieved December 5, 2018, from Faculty of Social Science and Humanities, and Religion: University of Capetown: https://open.uct.ac.za/bitstream/handle/11427/17492/thesis_hum_ 1997_kenan_john_sarauta.pdf?sequence $=1$

66. Khan A, Tshioko F, Heymann D, Le Guenno B, Nabeth P, Kerstiens B et al (1999) The reemergence of Ebola hemorrhagic fever Democreatic Republic of the Congo, 1995, Commission de Lutte Contre les Epidemies a Kikwit. J Infect Dis 179(1):S76

67. Kilmarx P, Clarke K, Dietz P, Hamel M, Husain F, McFadden J, Jambai A (2014) Ebola virus disease in health care workers - Sierra Leone, 2014. Morb Mortal Wkly Rep 63 (49):1168-1172

68. Klibanoff E (2014) Some airports have a new security routine: taking your temperature. Retrieved from NPR: goats and soda

69. Kortepeter M, Bausch D, Bray M (2011) Basic clinical and laboratory features of filoviral hemorrhagic fever. J Infect Dis 204(Suppl 3):S810-S816

70. Kreuels B, Wichmann D, Emmerich P, Schmidt-Chanasit J, de Heer G, Kluge S et al (2014) A case of severe Ebola virus infection complicated by gram-negative septicemia. N Engl J Med 371:2394-2401. https://doi.org/10.1056/NEJMoa1411677

71. Kuan M, Lin T, Chuang J, Wu H (2010) Epidemiological trends and the effect of airport fever screening on prevention of domestic dengue fever outbreaks in Taiwan, 1998-2007. Int J Infect Dis 14:e693-e697

72. Leroy E, Kumulungui B, Pourrut X, Roquert P, Hassanin A, Yaba P et al (2005) Fruit bats as reservoirs of Ebola virus. Nature 438:575-576

73. Levy B, Odoi A (2018) Exploratory investigation of region level risk factors of Ebola virus disease in West Africa. Peer J. Retrieved from https://peerj.com/articles/5888/

74. Levy Y, Lane C, Piot P, Beavogui A, Kieh M, Leigh B, Yazdanpanah Y (2018) Prevention of Ebola virus disease through vaccination: where we are in 2018. Lancet 392(10149):787-790

75. Lu H, Qian J, Kargbo D, Zhang X, Yang F, Hu Y et al (2015) Ebola virus outbreak investigation, Sierra Leone, September 28-November 11, 2014. Emerg Infect Dis 21(11):1921

76. Lyon G, Mehta A, Varkey J, Brantly K, Plyler L, McElroy A, Ribner B (2014) Clinical care of two patients with Ebola virus disease in the United States. N Engl J Med 371(25):2402 
77. Mananga G, Kapetshi J, Berthest N, Ilunga B, Kabange F et al (2014) Ebola virus disease in the Democratic Republic of Congo. N Engl J Med 371:2083-2091

78. Manguvo A, Mafuvadze B (2015) The impact of traditional and religious practices on the spread of Ebola in West Africa: time for a strategic shift. Pan Afr Med J 22(Suppl 1):9

79. Mate S, Kugelman J, Nyenswah T, Ladner J, Wiley M, Cordier-Lassalle T, Palacios G (2015) Molecular evidence of sexual transmission of Ebola virus. N Engl J Sci 373(25):2448

80. Mattia J, Vandy M, Chang J, Platt D, Dierberg K, Bausch D, Mishra S (2016) Early clinical sequelae of Ebola virus disease in Sierra Leone: a cross-sectional study. Lancet Infect Dis 16 (3):331-338

81. Maxmen A (2015) How the fight against Ebola tested a culture's traditions. National Geographic. Retrieved December 5, 2018, from https://news.nationalgeographic.com/2015/01/ 150130-ebola-virus-outbreak-epidemic-sierra-leone-funerals/

82. Metzger W, Vivas-Martinez S (2018) Questionable efficacy of the rVSV-ZEBOV Ebola vaccine. Lancet 391(10125):30560-30569

83. Mobula L, MacDermott N, Hoggart C, Brantly K, Plyer W, Brown J et al (2018) Clinical manifestations and modes of death among patients with Ebola virus disease. Am J Trop Med Hyg 94(4):1186-1193

84. Mokgobi M (2014) Understanding traditional African Healting. Afr J Phys Health Educ Recreat Dance 20(Suppl 2):24-34

85. Moskowitz P (2014) Deforestation, development may be driving Ebola outbreaks, experts say. AlJazeera America. Retrieved December 7, 2018, from http://america.aljazeera.com/articles/ 2014/8/4/ebola-deforestationclimatechange.html

86. Muyembe-Tamfum J, Kipasa M, Kiyungu C, Colebunders R (1999) Ebola outbreak in Kikwit, Democratic Republic of the Congo: discovery and control measures. J Infect Dis 179:S259S262

87. Nkoghe D, Formenty P, Leroy E, Nnegue S, Edou S, Ba J, Mve M (2005) Multiple Ebola virus haemorrhagic fever outbreaks in Gabon, from October 2001 to April 2002. Bull Soc Pathol Exot 98(3):224

88. Nordenstedt H, Bah E, de la Vega M, Barry M, N'Faly M, Crahay B et al (2016) Ebola virus in breast milk in an Ebola virus-positive mother with twin babies, Guinea, 2015. Emerg Infect Dis 22(4):759-760. https://doi.org/10.3201/eid2204.151880

89. Okware S, Omaswa F, Talisuna A, Amandua J, Amone J, Onek P et al (2015) Managing Ebola from rural to urban slum settings: expierences from Uganda. Afr Health Sci 15(1):312-321

90. Olivero J, Fa J, Real R, Marquez A, Farfan M, Vargas M et al (2017) Recent loss of closed forests is associated with Ebola virus disease outbreaks. Sci Rep 7:14291

91. Osemwenkha S (2000) Disease Aetiology in Traditional African Society. Afr: Riv Trimest Stud Documentazione Dell'Istituto Ital l'Afr l'Oriente 55(4):583-590

92. Palich R, Irenge L, Barte de Sainte Fare E, Augier A, Malw D, Gala J (2017) Ebola virus RNA detection on fomites in close proximity to confirmed Ebola patients; N'Zerekore, Guinea, 2015. PLoS One 12(5):e0177350

93. Paweska J, Storm N, Grobbelaar A, Markotter W, Kemp A, van Vuren J (2016) Experimental Inoculation of Egyptian Fruit Bats (Rousettus aegyptiacus) with Ebola Virus. Viruses 8:e29. https://doi.org/10.3390/v8020029

94. Prevention CF (2000) Public health screening at US ports of entry: guidelines for inspectors. Retrieved April 10, 2018, from http://www.library.armstrong.edu/eres/docs/eres/ETHI20001_ADAMS/200003adaEntryPart1.PDF

95. Prevention CF (2017) US quarantine stations. Retrieved from CDC: https://www.cdc.gov/ quarantine/quarantine-stations-us.html

96. Reiter P, Turell M, Coleman R, Miller B, Maupin G, Liz J et al (1999) Field investigations of an outbreak of Ebola hemorrhagic fever, Kikwit, Democratic Republic of the Congo, 1995: arthropod studies. J Infect Dis 179(Suppl 1):S148-S154

97. Rowe A, Bertolli J, Khan A, Mukunu R, Muyembe-Tamfum J, Bressler D et al (1999, Feb) Clinical, virologic, and immunologic follow-up of convalescent Ebola hemorrhagic fever 
patients and their household contacts, Kikwit, Democratic Republic of the Congo. Commission de Lutte contre les Epidémies à Kikwit. J Infect Dis 1:S28-S35

98. Sanchez R, Shoichet C, Karim F (2014) Ray Sanchez, Catherine E. Shoichet and Faith Karimi. Retrieved from CNN: https://www.cnn.com/2014/10/31/health/us-ebola/index.html

99. Schieffelin J, Shaffer J, Goba A, Gbankie M, Gire S, Colubri A, Garry R (2014) Clinical illness and outcomes in patients with Ebola in Sierra Leone. N Engl J Med 371(22):2092-2100

100. Selvey L, Antão C, Hall R (2015) Evaluation of border entry screening for infectious diseases in humans. CDC: Emerg Infect Dis 21, 197(2)

101. Shah J (2015) The dead bodies of the West African Ebola epidemic: understanding the importance of traditional burial practices. Inquiries J Soc Sci Art Humanit 7(11):1-4

102. Shantha J, Crozier I, Yeh S (2017) An update on ocular complications of Ebola virus disease. Curr Opin Opthalmol 28(6):600-606

103. Shears P, O'Dempsey T (2015) Ebola virus disease in Africa: epidemiology oand nosocomial transmission. J Hosp Infect 90(1):1-9

104. Sissoko D, Keita M, Boubacar D, Aliabadi N, Fitter D, Dahl B et al (2017) Ebola virus persistence in breast milk after no reported illness: a likely source of virus transmission from mother to child. Clin Infect Dis 64(4):513-516

105. Swanepoel R, Leman P, Burt F, Zachariades N, Braack L, Ksiazek T et al (1996) Experimental inoculation of plants and animals with Ebola virus. Emerg Infect Dis 2(4):321-325

106. Thompson E (1965) Primitive African medical Lore and Witchcraft. Bull Med Libr Assoc 53 (1):80-94

107. Tower J, Rolin P, Bausch D, Sanches A, Crary S, Vincent M et al (2004) Rapid diagnosis of Ebola hemorrhagic fever by reverse transcrpition-PCR in an outbreak setting and assessment of patient viral load as a predictor of outcome. J Virol 78(8):4338

108. Trevisanato S (2007) The 'Hittite plague', an epidemic of tularemia and the first record of biological warfare. Med Hypothesis 69(6):1371-1374

109. United Nations (2014) World's population increasingly urban with more than half living in urban areas. Retrieved from United Nations: http://www.un.org/en/development/desa/news/ population/world-urbanization-prospects-2014.html

110. Uyeki T, Mehta A, Davey R, Liddell A, Wolf T, Vetter P et al (2016) Clinical management of Ebola virus disease in the United States and Europe. N Engl J Med 374(7):636

111. Valeri L, Patterson-Lomba O, Yared G, Ablorh A, Bobb J, Townes W, Harling G (2016) Predicting subnational Ebola virus disease epidemic dynamics from sociodemographic indicators. PLoS One 11:e0163544

112. Varkey J, Shantha J, Crozier I, Craft C, Lyon G, Mehta A et al (2015) Persistence of Ebola virus in ocular fluid during convalescence. New Engl J Med 372:2423-2427. https://doi.org/ 10.1056/NEJMoa1500306

113. Victory K, Coronado F, Ifono S, Soropogui T, Dahl B (2015) Ebola transmission linked to a single traditional funeral ceremony - Kissidougou, Guinea, December, 2014-January 2015. MMWR Morb Mortal Wkly Rep 64(14):386-388

114. Vonnahme L, Jungerman M, Gulati R, Illig P, Alvarado-Ramy F (2017) US federal travel restrictions for persons with higher-risk exposures to communicable diseases of public health concern. Emerg Infect Dis 23, supplement. Retrieved from https://wwwnc.cdc.gov/eid/article/ 23/13/17-0386_article

115. Walsh M, Haseeb M (2015) The landscape configuration of zoonotic transmission of Ebola virus disease in West and Central Africa: interaction between population density and vegetation cover. PeerJ. https://doi.org/10.7717/peerj.735

116. Westhoff Smith D, Hill-Batorski L, N'jai A, Eisfeld A, Neumann G, Halfmann P, Kawaoka Y (2016) Ebola virus stability under hospital and environmental conditions. J Infect Dis 214 (Suppl 3):S142-S144

117. WHO (n.d.) Retrieved December 4, 2018, from Ground zero in Guinea: the Ebola outbreak smoulders - undetected - for more than 3 months: http://www.who.int/csr/disease/ebola/ ebola-6-months/guinea/en/ 
118. WHO (2014) Interim infection prevention and control guidance for care of patients with suspected or confirmed filovirus haemorrhagic fever in health-care settings, with focus on Ebola. Retrieved from WHO_HIS_SDS_2014.4_eng.pdf https://apps.who.int/iris/bitstream/handle/10665/130596/ WHO_HIS_SDS_2014.4_eng.pdf;jsessionid=88823349AEAFBF8D9188605A6C7C4B51? sequence $=1$

119. WHO (2016) World Health Organization. Clinical care for survivors of Ebola virus disease: interim guidance. April 2016. Retrieved Dec 3, 2018, from http://apps.who.int/iris/bitstream/ handle/10665/204235/WHO_EVD_OHE_PED_16.1_eng.pdf; jsessionid $=4014756$ C59CC9C80C419B41A08E73430?sequence $=1$

120. WHO (2018) Ebola virus disease: FAQ: compassionate use of Ebola vaccine in the context of the Ebola outbreak in North Kivu, Democratic Republic of the Congo. Retrieved December 6, 2018, from World Health Organization: https://www.who.int/ebola/drc-2018/faq-vaccine/en/

121. WHO Ebola Response Team (2014) Ebola virus disease in West Africa - the first 9 months of the epidemic and forward projections. N Engl J Med 371(1):1481-4195

122. WHO: International Commission (1978) Ebola haemorrhagic fever in Zaire, 1976. Bull World Health Organ 56(2):271-293

123. WHO: International Study Team (1978) Ebola haemorrhagic fever in Sudan, 1976. Bull World Health Organ 56(2):247-270

124. World Health Organization (2014) WHO interim guidance for Ebola: exit screening at airports, ports and land crossings. Retrieved from http://apps.who.int/iris/bitstream/handle/ 10665/139691/WHO_EVD_Guidance_PoE_14.2_eng.pdf; jsessionid $=64$ A1B9978B17C57D62739E56CFA7841C?sequence $=1$

125. World Health Organization (2014b, November 6) WHO Interim guidance for Ebola: exit screening at airports, ports and land crossings. Retrieved from http://apps.who.int/iris/ bitstream/handle/10665/139691/WHO_EVD_Guidance_PoE_14.2_eng.pdf; jsessionid=64A1B9978B17C57D62739E56CFA7841C? sequence $=1$

126. World Health Organization (2018) Ebola fact sheet. Retrieved from WHO: http://www.who. int/mediacentre/factsheets/fs103/en/

127. World Helth Organization (2018) Retrieved December 1, 2018, from Ebola situation reports: Democratic Republic of the Congo: http://www.who.int/ebola/situation-reports/drc-2018/en/

128. Yong E (2016) The CDC's new quarantine rule could violate civil liberties. The Atlantic. Retrieved from https://www.theatlantic.com/science/archive/2016/12/cdc-quarantine-rule-vio late-civil-liberties/511823/

129. Zaki S, Shieh W-J, Greer P, Goldsmith C, Ferebee T, Katshitshi J et al (1999) A novel immunohistochemical assay for the detection of Ebola virus in skin: implications for diagnosis, spread, and surveillance of Ebola hemorrhagic fever. J Infect Dis 179:S34-S47 